\title{
Agronomic and Physiological Evaluation of Egyptian Wheat Cultivars under Salinity Stress
}

\author{
Mohamed Ebaid ${ }^{1}$, Ali I. Nawar ${ }^{2}$, Sanaa I. Milad ${ }^{2}$, M.N. Barakat ${ }^{2}$ and O.M. Ibrahim ${ }^{1}$ \\ ${ }^{1}$ Plant production Dept., Arid Land Cultivating Research Institute, City of Scientific Research and \\ Technological Applications "SRTA-City", Egypt \\ ${ }^{2}$ Biotechnology Lab, Dept., of Crop Science, Faculty of Agriculture, El Shatby, Alexandria University, \\ Alexandria, Egypt.
}

Received: 11 Dec. 2018 / Accepted 28 Jan 2019 / Publication date: 30 Dec. 2019

\begin{abstract}
The objectives of this investigation were to study salt effects on grain yield, its components and some agronomic \& physiological traits of eleven bread wheat cultivars. These cultivars were grown in pots under greenhouse conditions, and subjected to four salinity levels (tap water (control), 3000, 6000 and 9000ppm), as dilutions of seawater. The experiment, in each year, was laid out in randomized complete block design and split-plot arrangement, with four replications. The results revealed that there were significant variations with all studied characters due to years( $\mathrm{Y}$ ) (except for number of spikes /pot and 100-grains weight), Salinity levels (S), wheat cultivars (C), $\mathrm{Y}^{*} \mathrm{~S}$ interaction (except for 100-grains weight), $\mathrm{Y} * \mathrm{~S}, \mathrm{~S} * \mathrm{C}$ and three factor interaction $\mathrm{Y} * \mathrm{~S} * \mathrm{C}$. The data in indicated that the significantly highest grain yield was obtained at $3000 \mathrm{ppm}$ salinity level and that character decreased significantly with lower or higher salinity levels. Cultivar Debiera recorded the highest grain yield $(12.65 \mathrm{~g})$ among all cultivars, which was not significantly different from Sakha 93 $(11.88 \mathrm{~g})$, while Gemmiza 9 ranked the lowest $(8.58 \mathrm{~g})$. Cultivars differed in their response to increased salinity levels. In general, all cultivars suffered reduction in grain yield increase in salinity level to $9000 \mathrm{ppm}$ ranging from 16.8 to $62.5 \%$. However, cultivars Giza 168, Giza 171 and Misr 2 recorded low reductions in the range from 16.8 to $32.0 \%$, while cultivars Sakha 8 and Sakha 93 suffered intermediate reductions in the range from 32.0 to $47.3 \%$. The highest reductions, in the range from 47.3 to $62.5 \%$, were recorded for Sids 1, Sids 13, Gemmiza 9, Gemmiza 12, Nubaria 1 and Debiera cultivars. According to salinity susceptibility index, cultivars were categorized into three groups, high tolerance to $9000 \mathrm{ppm}$ included Giza 168, Giza 171 and Misr 2 with SSI values ranging from 0.358 to 0.678. Cultivars that revealed intermediated tolerance included Sakha 8 and Sakha 93 with SSI values ranging from 0.678 to 0.998 . Finally, the last tolerant (susceptible) Cultivars included Sids 1, Sids 13, Gemmiza 12, Gemmiza 9, Nubaria and Debiera with SSI values ranging from 0.998 to 1.32.
\end{abstract}

Keywords: Wheat, Salinity stress, Grain yield, SSI.

\section{Introduction}

Salinity- pruned areas is a world-wide problem in agricultural systems. FAO (2015) estimated the global extent of saline and sodic soils to be $6.5 \%$ of the total cultivated area $(8.30$ million hectares), and about $19.5 \%$ of irrigated land (45million ha) was considered salt-affected. Egypt is one of the countries that encounter severe salinity problems, where about $30 \%$ of all irrigated lands is affected by salt (Zink, 2003 and Al-Naggar et al., 2015). Several factors combined to enhance the salinization of cultivated areas such as leakage of water from irrigation systems leading to rise of groundwater and extensive use of inorganic fertilizers.

Wheat is an important crop world wide and in Egypt. Due to the huge increase in population, the cultivated area in the Nile valley fell short to provide for the increasing consumption and growing of wheat was extended to newly reclaimed lands which are salt-affected with varying degrees (Milad et al., 2016).

Salinity impacts wheat plants, through the concentration of salt in soil solution, at various growth stages. Mujeeb et al. (2008) and El-Hendawy et al. (2012) found that increasing salinity levels reduced germination and early seedling growth of wheat cultivars. Vegetative growth of wheat was also reduced and shoot dry matter decreased with increasing salinity levels (Abdeshahian et al., 2010).

Corresponding Author: Mohamed Ebaid, Plant production Dept., Arid Land Cultivating Research Institute, City of Scientific Research and Technological Applications “SRTA-City”, Egypt. E-mail: eng_memo36@yahoo.com 
The damaging effects of increased salinity on physiological traits of wheat plant was expressed in reduced grain yield and yield components (Shafi et al., 2010 and Asgari et al., 2012), leaf area and pigment content (Shah et al., 2017) and photosynthetic rate (Abdeshahian et al., 2010).

Kalhoro et al. (2016) and Maha et al. (2017) reported that plant height, number of grains per spike and thousand grain weight of wheat genotypes were reduced with increasing salinity level. AL-Khaishany et al. (2018) tested ten wheat genotypes under a range of $\mathrm{NaCl}$ concentrations of 0 to $200 \mathrm{Mm}$ and found that increasing salinity level decreased agronomic traits of wheat genotypes. However, genotypes differed in their response from moderately tolerant to susceptible.

The present investigation was carried out to study the agrophysiological response of eleven Egyptian and one introduced wheat genotypes to salinity stress.

\section{Materials and Methods}

The present investigation was carried out at Plant Production Department, Arid Lands Cultivation Research Institute, City of Scientific Research and Technological Applications "SRTACity", New Borg El-Arab, Alexandria, Egypt, during the two winter seasons of 2014/2015 and 2015/2016. The experiments were conducted under greenhouse conditions. The eleven wheat cultivars (table1) were subjected to four levels of saline irrigation water (Cont.= control, tap water, SL.1=3000 ppm, SL. $2=6000 \mathrm{ppm}$ and SL. $3=9000 \mathrm{ppm}$, as dilutions of seawater).

Twenty seeds were planted in plastic pots $(25 \mathrm{~cm}$ in diameter and $20 \mathrm{~cm}$ in depth) filled with sandy clay loam. Sowing date was December $1^{\text {st }}$ in both years. The pots were irrigated using tap water until germination. After 21 days from sowing, ten plants were retained in each pot and the plants were subjected to salinity treatments.

Irrigation water was applied every 7 days until 45 days after sowing, then applied at 4 days interval. For control, the amount of water applied at each irrigation was $1 \mathrm{~L} /$ pot (according to determination of field capacity). However, an additional $25 \%$ was added, when irrigating with saline solutions, to supply leaching fraction requirements.

The experiment, in each year, was laid out in randomized complete block design and split-plot arrangement, with four replications. The main plots were occupied by water salinity levels while the wheat cultivars were allotted to the subplots. Data analysis were performed according to Gomez and Gomez (1984), using SAS program (SAS Inc., 1985), and means were compared using least significant difference (LSD) at 0.05 level of probability. Combined analysis of variance over seasons was performed for characters that exhibited homogeneity of error in the two seasons according to Hartley test (Winer et al., 1971).

The measured characters included flag leaf area, chlorophyll content (determined using chlorophyll fluorometer model OPTI-SCIENCES OS-30), number of spikes/pot, number of grains/ spike, 100-grain weight (as an average of three 100 grains samples) and grain yield/pot.

The Salinity susceptibility index (SSI), proposed by Fisher and Maurer (1978), was used to determine the tolerance of wheat cultivars to saline irrigation water.

Table 1: Names and pedigree for the bread wheat genotypes used in the present study.

\begin{tabular}{lll}
\hline No. & \multicolumn{1}{c}{$\begin{array}{c}\text { Genotype } \\
\text { name }\end{array}$} & Pedigree \\
\hline $\mathbf{1}$ & Giza 168 & MIL/BUC//Seri CM93046-8M-0Y-0M-2Y-0B-0SH \\
$\mathbf{2}$ & Giza 171 & Sakha 93/ Gemmeza9 S.6-1GZ-4GZ-1GZ-2GZ-0S \\
$\mathbf{3}$ & Sids 1 & HD2172/PAVON"S"//1158.57/MAYA74"S"SD46-4SD-2SD-1SD-0SD \\
$\mathbf{4}$ & Sids 13 & KAUZ"S"//TSI//TSI/SNB"S"ICW94-0375-4AP-2AP-030AP-0APS-3AP-0APS-050AP-0AP-0SD. \\
$\mathbf{5}$ & Misr 2 & SKAUZ/BAV92. CMSS96M03611S-1M-010SY-010M-010SY-8M-0Y-0EGY \\
$\mathbf{6}$ & Sakha 8 & Indus/ Norteno "S“Pk3418-6S-1SW-0S \\
$\mathbf{7}$ & Sakha 93 & Sakha 92/TR 810328-S.8871-1S-2S-1S-0S \\
$\mathbf{8}$ & Gemmiza 9 & Ald”S”/Huac”S"/CMH74A.630/5x CGM4583-5GM-1GM-0GM \\
$\mathbf{9}$ & Gemmiza 12 & OTUS/3/SARA/THB//VEE .CCMSS97Y00227S-5Y-010M-010Y-010M-2Y-1M-0Y-0GM \\
$\mathbf{1 0}$ & Nubaria 1 & OASIS/5*BOR95/5/CNDO/R143//ENTE/MEX175/3/CNDO/R143 \\
& & HD-2160/5/TOBARI-66/CIANO-67//BLUEBIRD/3/NAINARI-60*2//TOM-THUMB/SONORA- \\
$\mathbf{1 1}$ & Debiera & 64/4/HD-1954; HD-2160/5/TOBARI-66/CIANO-67//BLUEBIRD/4/NAINARI-60*2//TOM- \\
& & THUMB(TT)/SONORA-64/3/LERMA-ROJO-64/SONORA-64. HD-2172; HYBRID-DELHI- \\
\hline
\end{tabular}


Table 2: Weather data for Borg Elarab region in season from 2014/2015 to 2015/2016.

\begin{tabular}{lccccccc}
\hline Month & SRAD & T. Max & T. Min & Rain & TDew & Wind & RHUM \\
\hline Dec.2014 & 11.47 & 21.19 & 12.29 & 0.57 & 8.78 & 2.75 & 63.79 \\
Jan.2015 & 12.69 & 17.98 & 9.14 & 15.18 & 5.20 & 3.84 & 61.21 \\
Feb.2015 & 14.26 & 18.42 & 9.40 & 20.21 & 5.22 & 3.61 & 60.47 \\
Mar.2015 & 19.82 & 22.34 & 11.42 & 8.3 & 8.60 & 3.11 & 61.96 \\
Apr.2015 & 24.58 & 24.28 & 12.69 & 37.03 & 8.85 & 3.58 & 57.28 \\
& & & & & & & \\
Dec.2015 & 11.70 & 19.64 & 12.87 & 31.36 & 10.32 & 3.16 & 70.71 \\
Jan.2016 & 12.61 & 17.39 & 9.62 & 51.59 & 6.52 & 3.36 & 66.73 \\
Feb.2016 & 15.81 & 21.30 & 10.75 & 3.82 & 8.32 & 3.16 & 64.25 \\
Mar.2016 & 19.82 & 22.67 & 11.79 & 4.38 & 8.28 & 3.36 & 60.08 \\
Apr.2016 & 24.65 & 28.77 & 14.89 & 1.44 & 9.91 & 3.14 & 51.39 \\
\hline SRAD: Sor
\end{tabular}

SRAD: Solar radiation TDew: Dew-point temperature $\quad$ RHUM: Relative humidity

\section{Results and Discussion}

Agronomical and physiological traits, such as grain yield, grain number/spike, 100-grains weight and chlorophyll content, have been the most commonly used criteria for identifying salinity tolerance in crop plants. This is largely due to their ease of measurement and because, at the end, yield under salinity stress conditions is usually the ultimate character required for crop plants.

Six agronomical and physiological traits were tested and evaluated to study the effect of salinity stress; Flag leaf area, Chlorophyll content, Number of Spikes /pot, Number of Grains per Spike 100Grain Weight, Grain Yield per pot and Salinity Indices.

Comparison between the two seasons indicated that measured characters were higher in their value, significantly or insignificantly, in the second season compared to values of the first season (Table 3). That may be attributed to variation in climatic conditions between the two seasons (Table 2).

Table 3: Means of agronomical and physiological traits as influenced by the years over all salinity levels and wheat cultivars.

\begin{tabular}{ccccccc}
\hline Years & $\begin{array}{c}\text { Flag leaf } \\
\text { area }\end{array}$ & $\begin{array}{c}\text { Chlorophyll } \\
\text { content }\end{array}$ & $\begin{array}{c}\text { No. of } \\
\text { spikes/pot }\end{array}$ & $\begin{array}{c}\text { No of } \\
\text { Grains / Spike }\end{array}$ & $\begin{array}{c}\text { 100 Grains } \\
\text { Weight(g) }\end{array}$ & $\begin{array}{c}\text { Grain Yield } \\
\text { (g) }\end{array}$ \\
\hline Year 1 & $14.52^{\mathrm{b}}$ & $16.02^{\mathrm{b}}$ & $11.47^{\mathrm{a}}$ & $20.04^{\mathrm{b}}$ & $3.45^{\mathrm{a}}$ & $7.68^{\mathrm{b}}$ \\
Year 2 & $18.75^{\mathrm{a}}$ & $25.57^{\mathrm{a}}$ & $11.01^{\mathrm{a}}$ & $51.94^{\mathrm{a}}$ & $3.20^{\mathrm{a}}$ & $12.97^{\mathrm{a}}$ \\
\hline
\end{tabular}

Means with the same letter are not significantly different at 0.05 level of probability.

Combined analysis of variance indicated significant variation in all studied characters due to years $(\mathrm{Y})$ (except for number of spikes /pot and 100-grains weight), Salinity levels (S), wheat cultivars (C), $Y^{*} \mathrm{~S}$ interaction (except for 100-grains weight), $\mathrm{Y} * \mathrm{~S}, \mathrm{~S} * \mathrm{C}$ and three factor interaction $\mathrm{Y} * \mathrm{~S} * \mathrm{C}$.

\section{Flag leaf area $\left(\mathrm{cm}^{2}\right)$ :}

The data revealed that the flag leaf area was markedly decreased with increasing the salinity levels across wheat cultivars (Table 4). The highest average of flag leaf area, $\left(21.81 \mathrm{~cm}^{2}\right)$ was detected when plants received tap water compared with salinity levels. The increase in salinity levels from $3000 \mathrm{ppm}$ to $6000 \mathrm{ppm}$ and $9000 \mathrm{ppm}$ led to significant decrease in the mean values of flag leaf area, $\left(20.06,13.34\right.$ and $10.16 \mathrm{~cm}^{2}$, respectively).

Table 4: Means of agronomical and physiological traits as influenced by the salinity levels overall years and wheat cultivars.

\begin{tabular}{|c|c|c|c|c|c|c|}
\hline $\begin{array}{c}\text { Salinity } \\
\text { levels }\end{array}$ & $\begin{array}{c}\text { Flag leaf } \\
\text { area }\left(\mathrm{cm}^{2}\right)\end{array}$ & $\begin{array}{c}\text { Chlorophyll } \\
\text { content }\end{array}$ & $\begin{array}{c}\text { No. of } \\
\text { spikes/pot }\end{array}$ & $\begin{array}{c}\text { No. of } \\
\text { Grains / Spike }\end{array}$ & $\begin{array}{c}\text { 100-Grains } \\
\text { Weight(g) }\end{array}$ & $\begin{array}{c}\text { Grain } \\
\text { Yield (g) }\end{array}$ \\
\hline Control & $21.81^{\mathrm{a}}$ & $25.13^{a}$ & $12.81^{\mathrm{a}}$ & $34.68^{\mathrm{c}}$ & $3.89^{\mathrm{a}}$ & $11.89^{\mathrm{b}}$ \\
\hline $3000 p p m$ & $20.06^{\mathrm{b}}$ & $24.11^{\mathrm{b}}$ & $11.57^{\mathrm{b}}$ & $41.63^{\mathrm{a}}$ & $3.77^{\mathrm{a}}$ & $12.45^{\mathrm{a}}$ \\
\hline $6000 \mathrm{ppm}$ & $13.34^{\mathrm{c}}$ & $20.52^{\mathrm{c}}$ & $10.67^{\mathrm{c}}$ & $38.82^{b}$ & $3.33^{b}$ & $10.55^{\mathrm{c}}$ \\
\hline $9000 p p m$ & $10.16^{\mathrm{d}}$ & $13.43^{\mathrm{d}}$ & $9.92^{\mathrm{d}}$ & $28.84^{\mathrm{d}}$ & $2.32^{\mathrm{c}}$ & $6.42^{d}$ \\
\hline
\end{tabular}

Means with the same latter are not significantly different at 0.05 level of probability. 
Data in (Table 5) showed that flag leaf area widely varied among wheat cultivars. The cultivar "Debiera" produced the highest mean flag leaf area $\left(22.76 \mathrm{~cm}^{2}\right)$, which was not significantly different from Sids-1 $\left(21.5 \mathrm{~cm}^{2}\right)$ and Gemmiza-9 $\left(21.23 \mathrm{~cm}^{2}\right)$, whereas, " Gemmiza-12 " gave the significantly lowest mean flag leaf area $\left(11.73 \mathrm{~cm}^{2}\right)$.

Table 5: Means of agronomical and physiological traits as influenced by wheat cultivars overall years and salinity levels.

\begin{tabular}{lcccccc}
\hline \multicolumn{1}{c}{ Cultivars } & $\begin{array}{c}\text { Flag leaf } \\
\text { area }\end{array}$ & $\begin{array}{c}\text { Chlorophyll } \\
\text { content }\end{array}$ & $\begin{array}{c}\text { No. of } \\
\text { spikes/pot }\end{array}$ & $\begin{array}{c}\text { No. of Grains / } \\
\text { Spike }\end{array}$ & $\begin{array}{c}\text { 100 Grains } \\
\text { Weight (g) }\end{array}$ & $\begin{array}{c}\text { Grain } \\
\text { Yield g/pot }\end{array}$ \\
\hline Giza 168 & 13.82 & 17.94 & 11.44 & 35.64 & 3.31 & 10.30 \\
Giza 171 & 16.38 & 18.2 & 10.07 & 32.71 & 4.30 & 11.02 \\
Sids 1 & 21.5 & 18.56 & 10.91 & 35.53 & 3.09 & 10.66 \\
Sids 13 & 14.52 & 20.74 & 11.84 & 40.19 & 2.93 & 8.69 \\
Misr 2 & 15.97 & 22.38 & 11.56 & 38.42 & 3.49 & 8.99 \\
Sakha 93 & 15.10 & 20.49 & 11.78 & 35.44 & 3.14 & 11.00 \\
Sakha 8 & 14.12 & 21.64 & 11.59 & 36.29 & 3.81 & 11.88 \\
Gemmiza 12 & 11.73 & 20.07 & 10.56 & 34.09 & 3.17 & 10.55 \\
Gemmiza 9 & 21.23 & 20.35 & 10.56 & 30.58 & 3.06 & 8.58 \\
Nubaria 1 & 15.44 & 26.48 & 11.44 & 36.09 & 3.19 & 9.24 \\
Debiera & 22.76 & 21.82 & 11.91 & 41.24 & 3.10 & 12.65 \\
L.S.D 0.05 & 2.40 & 1.57 & 0.09 & 0.21 & 0.31 & 0.86 \\
\hline
\end{tabular}

Concerning the $\mathrm{Y}^{*} \mathrm{~S}{ }^{*} \mathrm{C}$ interaction, the performance of cultivars, as affected by salinity levels, differed in the two seasons (Table 6). Flag leaf area in Sids-1, for example, increased with application of $3000 \mathrm{ppm}$ compared to control in the first season, whereas the trend was reversed in the second season. Moreover, cultivar Sakha-93 exhibited reduction in flag leaf area when salinity level was increased from 6000 to $9000 \mathrm{ppm}$ in the first season, while in the second season, an opposite trend was observed.

Table 6: Means for flag leaf area trait as affected by the interaction between years, salinity levels and wheat cultivars.

\begin{tabular}{lcccccccc}
\hline \multicolumn{1}{c}{} & \multicolumn{3}{c}{$\mathbf{1}^{\text {st }}$ year } & \multicolumn{5}{c}{$\mathbf{2}^{\text {nd }}$ year } \\
Cultivars & Control & $\mathbf{3 0 0 0 p p m}$ & $\mathbf{6 0 0 0 p p m}$ & $\mathbf{9 0 0 0 p p m}$ & Control & $\mathbf{3 0 0 0 p p m}$ & $\mathbf{6 0 0 0 p p m}$ & $\mathbf{9 0 0 0 p p m}$ \\
\hline Giza 168 & 15.58 & 11.75 & 6.69 & 4.34 & 23.99 & 19.86 & 15.49 & 12.81 \\
Giza 171 & 21.20 & 18.31 & 9.69 & 5.66 & 26.77 & 22.63 & 17.60 & 12.74 \\
Sids 1 & 27.27 & 34.68 & 11.79 & 5.16 & 34.43 & 27.49 & 20.52 & 10.79 \\
Sids 13 & 25.20 & 13.67 & 9.10 & 5.81 & 16.62 & 19.59 & 15.48 & 10.70 \\
Misr 2 & 17.41 & 18.38 & 12.11 & 6.22 & 27.71 & 17.98 & 14.11 & 13.84 \\
Sakha 93 & 12.37 & 14.31 & 10.43 & 5.97 & 22.31 & 21.39 & 13.98 & 20.02 \\
Sakha 8 & 22.10 & 14.00 & 9.24 & 3.86 & 23.77 & 17.77 & 12.56 & 9.67 \\
Gemmiza 12 & 15.05 & 12.37 & 4.78 & 4.18 & 19.73 & 13.52 & 10.53 & 13.73 \\
Gemmiza 9 & 22.76 & 21.15 & 9.30 & 6.32 & 35.12 & 32.32 & 24.79 & 18.08 \\
Nubaria 1 & 27.99 & 24.57 & 14.51 & 7.83 & 15.69 & 12.19 & 12.32 & 8.43 \\
Debiera & 29.84 & 27.68 & 17.04 & 21.38 & 22.88 & 25.72 & 21.50 & 16.02 \\
\hline
\end{tabular}

L.S.D 0.05 for two cultivar means at the same level of salinity $=6.77$. L.S.D 0.05 for two cultivar means at different salinity levels $=8.17$

\section{Chlorophyll content:}

The data revealed that the Chlorophyll content, was markedly decreased with increasing the salinity levels across wheat cultivars. (Table 4). The highest average of Chlorophyll content (25.13) was detected when plants received tap water compared with salinity levels. Also, the increase in salinity levels from $3000 \mathrm{ppm}$ to $6000 \mathrm{ppm}$ and $9000 \mathrm{ppm}$ significantly decreased the mean values of Chlorophyll content (24.11, 20.52 and 13.43 respectively).

Means of the Chlorophyll content, as affected by cultivars, are presented in Table (5), where cultivar Nubaria-1 recorded the highest value (26.48) among all wheat cultivars, with a significant difference with another ten cultivars, while cultivar Giza 168 ranked the lowest value (17.94), with no significant difference with Giza 171 and Sids 1. The remaining cultivars gave intermediate values. 
Concerning the $\mathrm{Y}^{*} \mathrm{~S}{ }^{*} \mathrm{C}$ interaction, the first season, cultivars in control had significantly higher values for chlorophyll content than all cultivars treated with 9000 ppm SL-3 and same cultivars in SL2 (Giza 171, sids 1, sakha 8, Gemmiza 9 and Debiera) (Table 7). However, in the second season, significant difference in chlorophyll content were detected between control and SL-3 for two cultivars only (Sids 13 and Gemmiza 12).

Table 7: Means for chlorophyll content trait as affected by the interaction between years, salinity levels and wheat cultivars.

\begin{tabular}{|c|c|c|c|c|c|c|c|c|}
\hline \multirow[b]{2}{*}{ Cultivars } & \multicolumn{4}{|c|}{$1^{\text {st }}$ year } & \multicolumn{4}{|c|}{$2^{\text {nd }}$ year } \\
\hline & Control & 3000ppm & 6000ppm & 9000ppm & Control & 3000ppm & 6000ppm & 9000ppm \\
\hline Giza 168 & 17.71 & 18.97 & 11.84 & 3.22 & 23.62 & 23.76 & 23.34 & 21.05 \\
\hline Sids 1 & 21.33 & 19.38 & 12.33 & 3.68 & 24.17 & 25.89 & 24.89 & 16.82 \\
\hline Sids 13 & 25.60 & 23.27 & 10.74 & 5.32 & 27.77 & 29.55 & 27.22 & 16.50 \\
\hline Misr 2 & 23.30 & 25.25 & 19.65 & 4.93 & 27.58 & 27.93 & 27.40 & 23.03 \\
\hline Sakha 8 & 26.04 & 20.93 & 14.43 & 2.87 & 28.14 & 29.10 & 27.29 & 24.37 \\
\hline Gemmiza 12 & 15.38 & 19.12 & 11.15 & 2.56 & 30.43 & 31.65 & 27.39 & 22.84 \\
\hline Gemmiza 9 & 24.13 & 20.74 & 16.62 & 4.40 & 25.09 & 24.90 & 24.65 & 22.29 \\
\hline Nubaria 1 & 30.15 & 29.07 & 25.48 & 5.98 & 31.88 & 32.02 & 29.53 & 27.75 \\
\hline Debiera & 26.12 & 24.45 & 19.04 & 11.85 & 26.14 & 22.37 & 22.82 & 21.76 \\
\hline
\end{tabular}

L.S.D 0.05 for two cultivar means at the same level of salinity $=4.43$

L.S.D 0.05 for two cultivar means at different salinity levels $=7.03$

\section{Number of Spikes/pot:}

The data revealed that the number of spikes/pot, was markedly decreased with increasing the salinity levels across wheat cultivars.

Means in Table (4), indicated that the highest average of number of spikes/pot (12.81 spikes/pot) were detected when plants received tap water compared with salinity levels. Also, the increase in salinity levels from $3000 \mathrm{ppm}$ to $6000 \mathrm{ppm}$ and $9000 \mathrm{ppm}$ significantly decreased the mean values of number of spikes/pot (11.57, 10.67 and 9.92 spikes/pot, respectively).

Means of the number of spikes/pot, as affected by cultivars, are presented in Table (5), where cultivar Debiera recorded the highest value (11.91 spikes/pot) among all wheat cultivars, which was not significant different from Sids 13 (11.84 spikes/pot), whereas, cultivar Giza 171 gave the significantly lowest value (10.07 spikes/pot). The remaining cultivars gave intermediated values.

According to the results showed in (Table 8), the $\mathrm{Y} * \mathrm{~S} * \mathrm{C}$ interaction, the performance of cultivars, as affected by salinity levels, differed in the two seasons.

Table 8: Means for number of spikes/pot trait as affected by the interaction between years, salinity levels and wheat cultivars.

\begin{tabular}{lcccccccc}
\hline & \multicolumn{4}{c}{$\mathbf{1}^{\text {st }}$ year } & \multicolumn{4}{c}{$\mathbf{2}^{\text {nd }}$ year } \\
Cultivars & Control & $\mathbf{3 0 0 0 p p m}$ & $\mathbf{6 0 0 0 p p m}$ & $\mathbf{9 0 0 0 p p m}$ & Control & 3000ppm & 6000ppm & $\mathbf{9 0 0 0 p p m}$ \\
\hline Giza 168 & 15.00 & 10.75 & 10.00 & 9.25 & 13.25 & 12.00 & 10.50 & 10.75 \\
Giza 171 & 10.00 & 10.00 & 9.75 & 9.00 & 10.75 & 10.25 & 10.50 & 10.25 \\
Sids 1 & 16.00 & 11.75 & 9.75 & 10.00 & 10.25 & 10.25 & 10.00 & 9.25 \\
Sids 13 & 15.75 & 13.75 & 10.00 & 9.25 & 12.00 & 12.25 & 11.25 & 10.50 \\
Misr 2 & 14.50 & 11.00 & 10.50 & 10.00 & 13.75 & 11.75 & 11.00 & 10.00 \\
Sakha 93 & 13.75 & 11.00 & 11.75 & 9.50 & 12.50 & 13.00 & 11.75 & 11.00 \\
Sakha 8 & 12.75 & 11.75 & 10.00 & 11.25 & 12.00 & 12.75 & 11.75 & 10.50 \\
Gemmiza 12 & 11.50 & 10 & 10.75 & 11.25 & 10.25 & 10.50 & 10.50 & 9.75 \\
Gemmiza 9 & 11.25 & 10.25 & 9.50 & 9.25 & 13.00 & 11.00 & 10.50 & 9.75 \\
Nubaria 1 & 17.75 & 14.25 & 11.00 & 8.25 & 9.50 & 11.00 & 10.75 & 9.00 \\
Debiera & 15.50 & 14.25 & 11.75 & 10.50 & 10.75 & 11.00 & 11.50 & 10.00 \\
\hline
\end{tabular}

L.S.D 0.05 for two cultivar means at the same level of salinity $=0.26$. L.S.D 0.05 for two cultivar means at different salinity levels $=0.32$ 
The data revealed that the number of spikes/pot, was markedly decreased with increasing the salinity levels across wheat cultivars during the first season. However, in the second season the performance of the cultivars differed. For example, Sakha 93 gave an increase in the number of spike/pot at $3000 \mathrm{ppm}$ level compared to control and there was a decrease in the number of spikes /pot with increasing levels of salinity to $6000 \mathrm{ppm}$ and $9000 \mathrm{ppm}$.

\section{Number of Grains / Spike:}

The data in (Table 4) indicated that number of grains /spike in the second season was higher than that of the first season for all cultivars. The significantly highest number of grains/ spike was obtained at $3000 \mathrm{ppm}$ salinity level and that character decreased significantly with lower or higher salinity levels.

Means of the number of grains/spike, as affected by cultivars, are presented in (Table 5) where cultivar Debiera recorded the significantly highest value (41.24) among all wheat cultivars, while cultivar Gemmiza 9 gave the significantly lowest value (30.58), compered to the other ten cultivars. Concerning the $\mathrm{Y}^{*} \mathrm{~S} * \mathrm{C}$ interaction, the performance of cultivars, as influenced by salinity levels, varied from one season to another (Table 9). In the first season, some cultivars recorded significantly higher number of grains/ spike at 3000 ppm compared to the control (Gemmiza 9, Gemmiza 12 and Nubaria 1). However, in the second season, all cultivars recorded significantly higher value of number of grains/ spike at $3000 \mathrm{ppm}$ level compared to the control.

Table 9: Means for number of grains per spike trait as affected by the interaction between years, salinity levels and wheat cultivars.

\begin{tabular}{|c|c|c|c|c|c|c|c|c|}
\hline \multirow[b]{2}{*}{ Cultivars } & \multicolumn{4}{|c|}{$1^{\text {st }}$ year } & \multicolumn{4}{|c|}{$2^{\text {nd }}$ year } \\
\hline & Control & 3000ppm & $6000 \mathrm{ppm}$ & $9000 p p m$ & Control & 3000ppm & $6000 \mathrm{ppm}$ & 9000ppm \\
\hline Giza 168 & 18.25 & 16.05 & 16.25 & 10.40 & 51.25 & 63.55 & 63.15 & 46.25 \\
\hline Sids 1 & 19.80 & 18.20 & 18.15 & 13.15 & 49.10 & 64.40 & 58.00 & 43.40 \\
\hline Sids 13 & 24.50 & 25.95 & 20.25 & 15.10 & 58.85 & 63.35 & 60.40 & 53.15 \\
\hline Misr 2 & 27.85 & 27.65 & 25.65 & 16.05 & 51.75 & 59.15 & 53.65 & 45.60 \\
\hline Sakha 8 & 18.60 & 19.20 & 18.25 & 14.40 & 52.65 & 61.40 & 57.25 & 48.60 \\
\hline Gemmiza 12 & 20.15 & 23.90 & 17.35 & 7.85 & 46.15 & 62.40 & 53.35 & 41.60 \\
\hline Gemmiza 9 & 23.05 & 26.60 & 24.60 & 12.55 & 33.65 & 45.50 & 45.65 & 30.05 \\
\hline Nubaria 1 & 25.10 & 33.15 & 26.00 & 13.55 & 43.25 & 52.30 & 55.95 & 39.40 \\
\hline Debiera & 34.60 & 34.35 & 26.30 & 20.6 & 44.45 & 66.55 & 57.85 & 45.75 \\
\hline
\end{tabular}

L.S.D 0.05 for two cultivar means at the same level of salinity $=0.60$. L.S.D 0.05 for two cultivar means at different salinity levels $=0.77$

\section{0- Grains Weight (g):}

The data revealed that the 100- grains weight was markedly decreased, significantly or insignificantly with increasing the salinity levels across wheat cultivars (Table 4). The highest average of 100 - grains weight $(3.89 \mathrm{~g})$ were detected when plants received tap water compared with salinity levels. The increase in salinity levels $(3000 \mathrm{ppm}, 6000 \mathrm{ppm}$ and $9000 \mathrm{ppm})$ led to significant decrease in the mean values of 100 - grains weight $(3.77 \mathrm{~g}, 3.33 \mathrm{~g}$ and $2.32 \mathrm{~g}$ respectively).

Means of the 100- grains weight, as influenced by cultivars, are presented in (Table 5).C cultivar Giza171 recorded the significantly highest 100- grains weight $(4.30 \mathrm{~g})$ among all cultivars, while Sids-13 ranked the lowest (2.93g), which was not significantly from Gemmiza 9 (3.06g), Sids 1 (3.09g), Debiera (3.10g), Sakha 93 (3.14g), Gemmiza 12 (3.17g) and Nubaria 1 (3.19g).

Reading the $\mathrm{Y} * \mathrm{~S} * \mathrm{C}$ interaction, cultivars varied in their response to salinity levels in the two seasons (Table 10). For example, Giza 171 showed significant decrease in 100- grains weight with increasing salinity level from control to $3000 \mathrm{ppm}$ in the two seasons. Increasing salinity level to 9000 ppm caused significant reduction in that character, in Giza 171 of 62 and $48 \%$ in the first and second season, respectively. On the contrary, Sakha 8 cultivar recorded insignificant reduction in 100- grains weight at all salinity levels in the first season, whereas a significant reduction of almost $50 \%$, between control and $9000 \mathrm{ppm}$ level, was observed in the second season. 
Table 10: Means for hundred grains weight trait as affected by the interaction between years, salinity levels and wheat cultivars.

\begin{tabular}{|c|c|c|c|c|c|c|c|c|}
\hline \multirow[b]{2}{*}{ Cultivars } & \multicolumn{4}{|c|}{$1^{\text {st }}$ year } & \multicolumn{4}{|c|}{$2^{\text {nd }}$ year } \\
\hline & Control & $3000 p p m$ & $6000 \mathrm{ppm}$ & 9000ppm & Control & 3000ppm & $6000 \mathrm{ppm}$ & 9000ppm \\
\hline Giza 171 & 6.61 & 5.08 & 3.60 & 2.57 & 5.54 & 4.24 & 3.73 & 3.04 \\
\hline Sids 13 & 3.36 & 3.59 & 3.18 & 1.75 & 3.50 & 3.61 & 3.00 & 1.47 \\
\hline Misr 2 & 4.10 & 3.32 & 3.41 & 2.06 & 3.73 & 4.48 & 3.70 & 3.09 \\
\hline Sakha 93 & 2.52 & 3.87 & 2.71 & 2.15 & 3.53 & 3.89 & 3.46 & 2.95 \\
\hline Gemmiza 12 & 3.52 & 3.20 & 3.53 & 2.65 & 4.30 & 3.50 & 2.74 & 1.92 \\
\hline Gemmiza 9 & 4.44 & 4.57 & 4.14 & 2.35 & 2.72 & 2.40 & 2.65 & 1.19 \\
\hline Nubaria 1 & 3.56 & 4.24 & 3.07 & 2.99 & 3.76 & 2.95 & 3.05 & 1.93 \\
\hline Debiera & 2.92 & 3.17 & 3.47 & 2.63 & 4.96 & 3.08 & 2.73 & 1.84 \\
\hline
\end{tabular}

L.S.D 0.05 for two cultivar means at the same level of salinity $=0.87$. L.S.D 0.05 for two cultivar means at different salinity levels $=1.07$

\section{Grain Yield per pot $(\mathrm{g})$ :}

The data in (Table 4) indicated that the significantly highest grain yield was obtained at $3000 \mathrm{ppm}$ salinity level and that character decreased significantly with lower or higher salinity levels. Means of the grain yield, as influenced by cultivars, are presented in Table (5), where cultivar Debiera recorded the highest grain yield $(12.65 \mathrm{~g})$ among all cultivars, which was not significantly different from Sakha $93(11.88 \mathrm{~g})$, while Gemmiza 9 ranked the lowest $(8.58 \mathrm{~g})$, which was not significantly from Sids-13 (8.69g) and Misr $2(8.99 \mathrm{~g})$.

According to the results showed in (Table 11), the $\mathrm{Y} * \mathrm{~S} * \mathrm{C}$ interaction, the performance of cultivars, as affected by salinity levels, differed in the two seasons. The data revealed that the grain yield, was markedly decreased with increasing the salinity levels across wheat cultivars during the first season, while in the second season, grain yield of cultivars increased significantly or insignificantly, with application of $3000 \mathrm{ppm}$ compared to control, then decreased with increasing salinity levels to 6000 and 9000 ppm for all wheat cultivars.

Table 11: Means for grain yield trait as affected by the interaction between years, salinity levels and wheat cultivars.

\begin{tabular}{|c|c|c|c|c|c|c|c|c|}
\hline \multirow[b]{2}{*}{ Cultivars } & \multicolumn{4}{|c|}{$1^{\text {st }}$ year } & \multicolumn{4}{|c|}{$2^{\text {nd }}$ year } \\
\hline & Control & 3000ppm & $6000 \mathrm{ppm}$ & $9000 p p m$ & Control & $3000 p p m$ & 6000ppm & 9000ppm \\
\hline Giza 168 & 8.28 & 7.21 & 5.93 & 4.75 & 13.25 & 17.05 & 15.41 & 10.54 \\
\hline Giza 171 & 6.99 & 8.94 & 6.65 & 4.97 & 12.98 & 19.48 & 17.23 & 10.89 \\
\hline Sids 1 & 13.00 & 11.71 & 8.30 & 4.60 & 13.78 & 16.57 & 10.62 & 6.74 \\
\hline Sids 13 & 8.86 & 8.86 & 6.31 & 3.67 & 10.81 & 13.01 & 11.78 & 6.23 \\
\hline Misr 2 & 8.92 & 9.16 & 7.54 & 6.55 & 9.46 & 11.49 & 10.00 & 8.80 \\
\hline Gemmiza 12 & 11.58 & 8.06 & 6.83 & 3.41 & 16.07 & 16.96 & 13.92 & 7.56 \\
\hline Gemmiza 9 & 7.20 & 6.89 & 7.01 & 2.66 & 12.26 & 14.10 & 12.92 & 5.60 \\
\hline Nubaria 1 & 10.96 & 7.49 & 4.57 & 3.13 & 14.77 & 15.00 & 11.19 & 6.85 \\
\hline Debiera & 13.91 & 11.68 & 9.08 & 5.74 & 18.27 & 17.31 & 16.46 & 8.75 \\
\hline
\end{tabular}

L.S.D 0.05 for two cultivar means at the same level of salinity = 3.01. L.S.D 0.05 for two cultivar means at different salinity levels $=3.62$.

\section{The salinity susceptibility index (SSI):}

For the $3000 \mathrm{ppm}$ salinity level, all cultivars except Gemmiza 12, Nubaria 1, Sakha 93 and Debiera gave higher values for grain yield compared to control (Table 12). However, due to the high mean for all cultivars at that level, compared to the control. The SSI value took a negative sign. Increasing the salinity level to $6000 \mathrm{ppm}$, same cultivars showed high tolerance (SSI value less than one) such as Giza 171, Gemiza 9 and sakha 8, whereas cultivars Giza 168, Sids 13 and Misr 2 showed tolerance to that level of salinity. All wheat cultivars suffered loss in grain yield with increasing salinity level to $9000 \mathrm{ppm}$ with varying degrees compared to control. Cultivars that showed high tolerance to $9000 \mathrm{ppm}$ included Giza 168, Giza 171 and Misr 2 with SSI values ranging from 0.358 to 0.678. Cultivars that revealed intermediated tolerance included Sakha 8 and Sakha 93 with SSI values 
ranging from 0.678 to 0.998. Finally, the last tolerant (susceptible) Cultivars included Sids 1, Sids 13, Gemmiza 12, Gemmiza 9, Nubaria and Debiera with SSI values ranging from 0.998 to 1.32.

Table 12: The salinity susceptibility index (SSI) for wheat genotypes under increasing salinity levels in 2014/2015 and 2015/2016 seasons.

\begin{tabular}{lccccccc}
\hline Cultivars & Control & 3000ppm & SSI & 6000ppm & SSI & 9000ppm & SSI \\
\hline Giza 168 & 10.77 & 12.13 & 2.717 & 10.67 & 0.082 & 7.64 \\
Giza 171 & 9.985 & 14.215 & 8.473 & 11.94 & -1.717 & 7.93 \\
Sids 1 & 13.395 & 14.14 & 1.112 & 9.435 & 2.593 & 5.67 & 0.630 \\
Sids 13 & 9.835 & 10.935 & 2.237 & 9.045 & 0.705 & 4.95 & 1.251 \\
Misr 2 & 9.19 & 10.33 & 2.481 & 8.77 & 0.401 & 7.675 & 0.358 \\
Sakha 93 & 12.765 & 12.125 & -1.003 & 11.11 & 1.137 & 7.975 \\
Sakha 8 & 12.38 & 14.295 & 3.094 & 14.005 & -1.151 & 6.825 \\
Gemmiza 12 & 13.825 & 12.51 & -1.902 & 10.375 & 2.189 & 5.485 \\
Gemmiza 9 & 9.73 & 10.495 & 1.572 & 9.965 & -0.212 & 4.13 & 0.973 \\
Nubaria 1 & 12.865 & 11.24 & -2.526 & 7.88 & 3.399 & 4.99 & 1.248 \\
Debiera & 16.09 & 14.495 & -1.983 & 12.77 & 1.810 & 7.25 \\
$\overline{\text { Y }}$ & 11.90 & 12.45 & & 10.54 & & 6.41 \\
\hline
\end{tabular}

Wheat plant responses to salinity are complex and depend upon a number of factors, e.g. growth stage, concentration and type of salts (Cramer, 2002; Saqib, 2002 and Khan et al., 2010). In general, salinity seriously affects different growth characters and yield of wheat like other field crops. Yield reduction may range from slight loss to complete crop failure depending upon severity of the salinity problem and the wheat genotype (Chang and Sipio, 1991). In the present study, salinity at 6000 and $9000 \mathrm{ppm}$ sea water levels caused reduction in grain yield of 11.3 and $46.0 \%$ respectively as an average for all cultivars. Khan et al. (2010) reported a reduction in grain yield/plant due to salinity ranging from 34.3 to $67.0 \%$, depending on wheat genotype.

Reduction in grain yield due to the elevated level of salinity was associated with reduction in studied yield attributes, such as NSPP, NGPS and HGW. According to Kamkar et al. (2004) and Maha et al. (2017), salinity reduces yield primarily by a severe reduction in grain number and then by reduction in grain yield. Increasing salinity levels consistently decreased NSPP and HGW from control to $9000 \mathrm{ppm}$. Reductions in those two characters reached 22.6 and $40.4 \%$ at $9000 \mathrm{ppm}$ level compered to control. On the other hand, increasing salinity levels caused increase in NGPS of 20 and $12 \%$ at 3000 and $6000 \mathrm{ppm}$ levels, respectively, whereas the $9000 \mathrm{ppm}$ level recorded a reduction of $16.8 \%$ in NGPS compared to the control.

Salinity stress at different phenological stages inhibits photosynthetic activities of the plant because it had a direct inhibitory effect on the Calven cycle enzymes (Ottander and Oquist, 1991). Found that tillers/plant was the most salinity sensitive trait in wheat El-Hendawy et al. (2005). They concluded that to increase yield under salinity stress conditions, it is necessary to maintain high plant density. Mass and Poss (1989), concluded that growth of tillers at all stages was inhibited by salinity due to its damage on the essential metabolic reaction in plants resulting in low tiller biomass and small tiller size.

Katerji et al. (2009) and Al-Khaishany et al. (2018), reported differential response of cultivars to increase in salinity levels with regard to grain yield. Cultivars differed in their response to increased salinity levels. In general, all cultivars suffered reduction in grain yield increase in salinity level to $9000 \mathrm{ppm}$ ranging from 16.8 to $62.5 \%$. However, cultivars Giza 168, Giza 171 and Misr 2 recorded low reductions in the range from 16.8 to $32.0 \%$, while cultivars Sakha 8 and Sakha 93 suffered intermediate reductions in the range from 32.0 to $47.3 \%$. The highest reductions, in the range from 47.3 to $62.5 \%$, were recorded for Sids 1, Sids 13, Gemmiza 9, Gemmiza 12, Nubaria 1 and Debiera cultivars.

\section{References}

Abdeshahian, M., M.Nabipour, and M. Meskarbashee, 2010. Chlorophyll fluorescence as criterion for the diagnosis salt stress in wheat (Triticum aestivum) plants. Int. J. Chem. Biol. Eng., 4, 184186. 
Al-Khaishany, M.Y., F.H. Al-Qurainy, I.A. Alaraidh, M.N. Barakat, A. Ahmed, M.H. Elshafei, and M. Ishfaq, 2018. Genetic Variation of Wheat for Salt Tolerance Based on Physiological and Agronomic Traits. International Journal of Agriculture and Biology, 20(12), 2853-2861.

Al-Naggar, A.M.M., S.R.S. Sabry, M.M.M. Atta, and O.M.A. El-Aleem, 2015. Effects of Salinity on Performance, Heritability, Selection Gain and Correlations in Wheat (Triticum aestivum L.) Doubled Haploids. Scientia, 10(2), 70-83.

Asgari, H.R., W. Cornelis, and P.Van Damme, 2012. Effect of salinity on wheat (Triticum aestivum L.) grain yield, yield components and ion uptake. Desert, 16(2), 167-174.

Chang, M.H. and Q.A. Sipio, 1991. Salt tolerance of two varieties. J. Drainge Recl., 3: 36-39.

Cramer, G.R, 2002). Sodium-calcium interactions under salinity stress. In: Läuchli, A., Lüttge,U., (Eds.), Salinity: Environment - Plants - Molecules, Kluwer Academic Pubishers, Netherlands., pp.327-339.

El-Hendawy, S.E., Y. Hu, G.M. Yakout, A.M. Awad, S.E. Hafiz and U. Schmidhalter, 2005. Evaluating salt tolerance of wheat genotypes using multiple parameters. Eur. J. Agron., 22, 243-253.

El-Hendawy, S.E., Y. Hu, J.I. Sakagami, and U. Schmidhalter, 2012. Screening Egyptian wheat genotypes for salt tolerance at early growth stages. International Journal of Plant Production, 5(3), pp.283-298.

FAO, 2015. Extent of salt - affected soils. http: // www. FAO. Org/soils- portal /soil - management/ management - of -some - problem - soil / salt - affected - soils /more - information - on - salt - affected - soils / en /.

Fischer, R.A. and R. Maurer, 1978. Drought resistance inspring wheat cultivars. I. Grain yield responses. Crop and Pasture Science, 29(5): 897-912.

Gomez, K.A. and A.A. Gomez, 1984. Statistical procedures for agricultural research. John Wiley and Sons.

Kalhoro, N.A., I. Rajpar, S.A. Kalhoro, A. Ali, S. Raza, M. Ahmed and F. Wahid, 2016. Effect of salts stress on the growth and yield of wheat (Triticum aestivum L.). Am. J. Plant Sci., 7, 22572271.

Kamkar, B., M. Kafi and M. Nassiri-Mahallati, 2004. September. Determination of the most sensitive developmental period of wheat (Triticum aestivum) to salt stress to optimize saline water utilization. In $4^{\text {th }}$ International Crop Science Congress (pp. 1-6).

Katerji, N., M. Mastrorilli, J.W. van Horn, F.Z. Lahmer, A. Hamdy, and T. Oweis, 2009. Durum wheat and barley productivity in saline -drought environments. Eur. J. Agron., 31:1-9.

Khan, M. A., Islam, E., Shirazi, M. U., Mumtaz, S., Mujtaba, S. M., Khan, M. A. and Kaleri, G. M. 2010. Physiological responses of various wheat genotypes to salinity. Pak. J. Bot., 42(5), 3497.

Maha, A., I. Sanaa, Y.M. Mabrook, Y. Amira, and M.A. Gouda, 2017. Evaluation of some Egyptian bread wheat (Triticum aestivum) cultivars under salinity stress. Alexandria Science Exchange Journal, 38, 259-270.

Mass, E.V. and J.A. Poss, (1989). Salt sensitivity of cowpea at various growth stages. Irri. Sci., 10:313-320.

Milad, S. I., A. I. Nawar, A. M. Shaalan, M. Eldakak and Jai S. Rohila, 2016. Response of Different Wheat Genotypes to Drought And Heat Stresses During Grain Filling Stage. Egypt, J. Agron .Vol. 38, No.3, pp.369-387.

Mujeeb-Kazi, A., A. Gul, M. Farooq, S. Rizwan, and I. Ahmad, 2008. Rebirth of synthetic hexaploids with global implications for wheat improvement. Aust. J. Agric. Res. 59: 391-398.

Ottander, C. and G. Öquist, 1991. Recovery of photosynthesis in winter-stressed Scots pine. Plant, Cell and Environment, 14(3), pp.345-349.

Saqib, M., 2002. Selection and characterization of wheat genotypes against salinity and water logging. Ph.D. Thesis. Department of Soil Science University of Agriculture, Faisalabad, Pakistan.

SAS Institute Inc, 1985. SAS Online Doc, Version 8. SAS Institute Inc., Cary, NC.

Shafi, M., J. Bakhat, M. J.Khan, M. A.Khan, and S. Anwar, 2010. Effect of salinity on yield and ion accumulation of wheat genotypes. Pakistan Journal of Botany, 42(6), 4113-4121. 
Shah, S.H., R. Houborg, and M.F. McCabe, 2017. Response of Chlorophyll, Carotenoid and SPAD502 Measurement to Salinity and Nutrient Stress in Wheat (Triticum aestivum L.). Agronomy, 7(3), p.61.

Winer, B.J., D.R. Brown, and K.M. Michels, 1971. Statistical principles in experimental design (Vol. 2). New York: McGraw-Hill.

Zink, J. A., 2003. Monitoring Soil Salinity from Remote Sensing Data. $1^{\text {st }}$ Workshop EARSel Special Interest Group on Remote Sensing for Developing Countries, Gent, Belgium. 